\title{
Development and Preliminary Validation of the Shared Professional Leadership Inventory for Teams (SPLIT)
}

\author{
Amelie Grille*, Simone Kauffeld \\ Department of Industrial/Organizational and Social Psychology, Technische Universität Braunschweig, \\ Braunschweig, Germany \\ Email: ${ }^{*}$ a.grille@tu-braunschweig.de
}

Received 29 December 2014; accepted 16 January 2015; published 23 January 2015

Copyright (C) 2015 by authors and Scientific Research Publishing Inc.

This work is licensed under the Creative Commons Attribution International License (CC BY). http://creativecommons.org/licenses/by/4.0/

cc) (i) Open Access

\begin{abstract}
Shared leadership is viewed as an effective management form to encounter increased complexity in modern work life. However, the lack of reliable and valid instruments to assess shared leadership behaviors has limited empirical research. Based on literature in leadership and team work research a questionnaire was developed to assess four different aspects of shared leadership behavior-task-, relation-, change- and micropolitic-oriented leadership. The final version consisted of 20 items. Confirmatory factor analyses confirmed the theoretically hypothesized model in two independent German samples. Significant correlations with related scales support convergent and criterion validity. This study therefore provides researchers with a valid and reliable instrument to assess different aspects of shared leadership behavior and its advantages for research and human resource development are discussed.
\end{abstract}

\section{Keywords}

Shared Leadership, Validation, Questionnaire, Confirmatory Factor Analysis

\section{Introduction}

The importance of leadership for facilitating effective team performance has been investigated for decades (e.g., Fleishman, 1953; Judge, Piccolo, \& Ilies, 2004; Nisjstad, Berger-Selman, \& De Dreu, 2014; Yukl, Gordon, \& Taber, 2002). The majority of research focused on the effect of a single leader on team performance (Clarke, 2013; Morgeson, DeRue, \& Karam, 2010). However, more recently researchers began to investigate "an emer-

${ }^{*}$ Corresponding author. 
gent team property that results from the distribution of leadership influence across multiple team members" (Hoch, Pearce, \& Welzel, 2010b: p. 105). This dynamic process, described as "shared leadership" in the literature (e.g., Pearce \& Sims, 2002; Wang, Waldmann, \& Zhan, 2014), is seen as a new form of management (Pearce \& Manz, 2005) especially fit to encounter the increasing complexity of working life in which a single leader is unable to effectively perform all important leadership functions (Small \& Rentsch, 2010). Shared leadership is not intended to replace vertical leadership (Hoch et al., 2010b; Pearce \& Sims, 2002) but to enhance teamwork effectiveness (Ensley, Hmieleski, \& Pearce, 2006; Carson, Tesluk, \& Marrone, 2007).

Researchers have studied different shared leadership antecedents and outcomes empirically (e.g., Carson et al., 2007; Ensley et al., 2006; Hmieleski, Cole, \& Baron, 2012; Hoch, 2013; Liu, Hu, Li, Wang, \& Lin, 2014; Pearce \& Sims, 2002). However, compared to the number of papers forwarding theoretical assumptions about antecedents and relevant consequences of shared leadership, empirical evidence on shared leadership antecedents and consequences is still claimed to be scarce (Hoch, 2013; Pearce, Hoch, Jeppesen, \& Wegge, 2010). One explanation for this lack of empirical research may be a paucity of reliable and valid measures to assess shared leadership suitable for practical application even though the need for such measures has often been expressed (e.g., Avolio, Sivasubramaniam, Murry, Jung, \& Garger, 2003; Gockel \& Werth, 2010; Hiller, Day, \& Vance, 2006).

So far, researchers have used different methods to assess shared leadership, all of which however suffer from limitations. Some researchers have used network analyses to assess shared leadership (e.g., Carson et al., 2007; Liu et al., 2014; McIntyre \& Foti, 2013; Mehra, Smith, Dixon, \& Robertson, 2006; Small \& Rentsch, 2010). For example, team members were asked to nominate other team members whom they considered a leader. The number of leader nominations across the team indicated a higher degree of shared leadership (McIntyre \& Foti, 2013; Mehra et al., 2006).

Although network approaches accurately assess interactional processes in organizations (Hatala, 2006; Zhang, Zheng, \& Wei, 2009), they are complex and time consuming (Gockel \& Werth, 2010). Therefore, their applicability to practice may be limited. Furthermore, assessing who is perceived to be a leader provides no information about the types of shared leadership behaviors. Leadership behaviors are particularly relevant, because results could provide information for human resource development, for example, to support team members in learning and executing effective leadership behaviors. Moreover, assessing leadership behaviors accounts more for the conception of shared leadership as a dynamic process in which leadership behavior is distributed across team members rather than as a fixed state in which several individuals are seen as leaders (Hoch et al., 2010b; Pearce \& Sims, 2002).

To capture different facets of shared leadership behavior in teams, some researchers have therefore used video analysis to examine emerging leadership behaviors (e.g., Bergman, Rentsch, Small, Davenport, \& Bergman, 2012; Künzle, Zala-Mezö, Kolbe, Wacker, \& Grote, 2010). Such methods, however, are also time consuming and sometimes not practicable (Agnew, Carlston, Graziano, \& Kelly, 2009). To address the need for expediency, questionnaires have been developed to assess shared leadership behaviors (e.g., Avolio et al., 2003; Hiller et al., 2006; Hoch, Duhlebohn, \& Pearce, 2010a). However, to the best of our knowledge, detailed reports on psychometric evaluation of these instruments in scientific journals have not yet been published. Furthermore, various vertical leadership behaviors have been found to be crucial for team effectiveness. Thus, behavioral aspects not yet assessed by those instruments may be essential for understanding shared leadership processes.

Given the increased interest in shared leadership, additional valid, reliable and time-efficient questionnaires assessing a broad range of leadership behaviors are still needed. The present study's aim therefore is to develop a concise and widely applicable shared leadership questionnaire, to assess different dimensions of leadership behavior identified in the literature and to evaluate the psychometric properties of this instrument in two studies. We will call this newly developed questionnaire the Shared Professional Leadership Inventory for Teams (SPLIT).

\section{Literature Review}

In the following sections, we will first review strengths and limitations of questionnaires that have previously been created and used to assess shared leadership. We will hence continue with reviewing existing leadership behavior research to identify shared leadership behavior dimensions to be included into SPLIT.

\subsection{Questionnaires Assessing Shared Leadership Behavior}

Some researchers have taken existing vertical leadership questionnaires and changed their items’ wording to as- 
sess shared leadership (Ensley et al., 2006; Hmieleski et al., 2012). However, they did not conduct validations studies for the evaluation of measurement criteria for these newly developed scales. Other researchers have created new scales designed specifically to measure certain aspects of shared leadership behaviors and have reported first validity findings for their scales.

The Team Multifactor Leadership Questionnaire (TMLQ). Avolio, Sivasubramaniam, Murry, Jung and Garger (2003) reported preliminary data on the validity of shared leadership scales. The authors replicated the factor structure in different samples based on team data, but they did not explore the nested data structure. Additional findings on convergent, discriminant, and criterion validity have not been reported.

The Shared Leadership Questionnaire (SLQ). Hoch, Dulebohn and Pearce (2010a) presented first validity findings in a conference presentation of another shared leadership instrument based on Pearce and Sims (2002). The authors aggregated individual shared leadership ratings to the team level and were able to confirm the factor structure in different samples. They also reported the instrument's criterion validity showing high correlations with team performance. The questionnaire has already been used successfully in a study examining shared leadership antecedents and outcomes (Hoch, 2013). However, the authors have not yet reported in detail on the development of their scales or the validation process in a written publication.

Content focus of the TMLQ and the SLQ. Both instruments mainly relied on the vertical dimensions of transformational and transactional leadership, which were first introduced by Burns (1978) and then adapted to the team context. Transformational leadership describes a leader's efforts in motivating staff to become more aware of task importance, more engaged in the process, and more proud of their performance, for example, by providing vision and using inspirational communication (Pearce \& Sims, 2002). Transactional leadership involves reinforcing staff through rewards for their actions (Pearce \& Sims, 2002; Bass, 1990). Empirical research in the context of vertical leadership has provided support for the distinction of these two leadership dimensions (Avolio, Bass, \& Jung, 1999; Bass, 1990), and both dimensions have been studied extensively in the last 30 years (e.g., Eagly, Johannesen-Schmidt, \& van Engen, 2003; Judge \& Piccolo, 2004; Kuchinke, 1998; Lowe, Kroeck, \& Sivasubramaniam, 1996; Hamstra, Yperen, Wisse, \& Sassenberg, in press; Waldman, Bass, \& Einstein, 1987; Walumbwa, Orwa, Wang, \& Lawler, 2005). However, the transformational-transactional model of leadership has also been criticized for neglecting leaders' influence on group processes by focusing too much on dyadic processes (Morgeson et al., 2010; Yukl, 1999).

Questionnaire by Hiller, Day, and Vance (2006). Research on vertical leadership has also distinguished between task- and relation-oriented leadership as two major dimensions accounting for leadership effectiveness (Fleishman, 1953; Judge \& Piccolo, 2004; Yukl et al., 2002). Hiller et al. (2006) based their shared leadership scales on these two dimensions. Aggregating individual shared leadership ratings to the team level, the authors identified the two dimensions in a confirmatory factor analysis. High internal scale reliabilities as well as positive correlations between the scales and team collectivism and team performance provided first indications of the instrument's validity. However, these findings have not been empirically replicated in another sample.

Conclusion about current methods to assess shared leadership. Important initial efforts have been made to establish scales for assessing shared leadership behaviors. However, detailed studies of scale development and psychometric properties and replication of these studies have not yet been published. Furthermore, the development of these instruments has relied on traditional leadership theories, thus failing to include findings from teamwork research, which could have yielded additional information about the types of behaviors team members can successfully employ.

Given the lack of consensus on which leadership behaviors are relevant for sharing, we took a closer look at both leadership and teamwork literature to identify leadership behaviors that are particularly suitable for sharing by team members.

\subsection{Identifying Leadership Behavior Dimensions for SPLIT}

Various vertical leadership behaviors have been identified as effective (Avolio et al., 1999; House, 1996; Judge et al., 2004; Yukl et al., 2002). However, different terms have been used to describe similar leadership behaviors or researchers have used the same terms but defined them differently (Yukl et al., 2002).

Task and relation leadership orientation. The inconsistency of leadership behavior explanations notwithstanding, two major dimensions have frequently emerged since the influential Ohio State studies (e.g., Fleishman, 1953)-initiating structure and consideration. Initiating structure refers to all activities intended to organize and structure the team members' work. Similar behaviors have since been identified and referred to as direc- 
tive, or more commonly, task-oriented leadership (Bass, 1990; House, 1996; Pearce \& Sims, 2002; Yukl et al., 2002). In a meta-analysis, these activities were shown to be strongly related to organizational performance (Judge et al., 2004).

Consideration indicates the extent that leaders appreciate, respect, value the opinions of, and make efforts to be emotionally connected to team members (Fleishman, 1953; House, 1996). Researchers have emphasized such relation-oriented leadership behaviors as important for teamwork outcomes (e.g., Yukl et al., 2002; Bass, 1990). These behaviors were found to be strongly related to performance and to be especially linked to team members' motivation and job satisfaction (Clarke, 2012; Judge et al., 2004).

Change leadership orientation. Although task- and relation-oriented leadership have dominated leadership research, scholars have also identified additional aspects of leadership behavior that account for more variance in leadership effectiveness (e.g., Seltzer \& Bass, 1990; Yukl et al., 2002). In comprehensive review of leadership research from the last 50 years, Yukl, Gordon and Taber (2002) identified change-oriented leadership as a third meta-category crucial for leadership effectiveness. This style of leadership has recently gained relevance to account for exigencies of transformation and change in a globalized economy (Gil, Rico, Alcover, \& Barrasa, 2005; Sheehan, Garavan, \& Carbery, 2014). As a result, effective leaders are described as agents of change (Bass, 1990) who are skilled in providing a vision that inspires others and encourages innovation and modernization (Gilley, Dixon, \& Gilley, 2008; Waite, 2013; Williams \& Foti, 2011). These tasks are also integral to transformational leadership theory (Burns, 1978; Yukl et al., 2002), which might explain the recent popularity of this concept (Avolio, Reichard, Hannah, Walumbwa, \& Chan, 2009).

Micropolitical leadership orientation. Engaging in network activities has attracted attention in recent years as another important behavior for leadership effectiveness, although it has been neglected in most leadership theories. Yukl and colleagues (2002) consider network activities as important within the framework of changeoriented leadership, but other researchers describe networking activities as essential behaviors for effective leadership in general (Bono \& Anderson, 2005; Brass, 2001; Kotter, 2001; Nakamura \& Yorks, 2011). Networking has been found to be effective in several ways. By using personal network connections with other organizational units or external parties, team leaders can provide their staff with important resources, for example, by allocating required materials, machines, or expert knowledge (Balkundi \& Kilduff, 2006; Cross \& Prusak, 2002; Morgeson et al., 2010). Leaders can take the role of brokers to provide a bridge between people who are not in direct contact, which is likely to enhance network ties and team processes (Balkundi \& Kilduff, 2006). The evidence thus suggests that networking is an additional category contributing to variation in leader effectiveness. Actively using one's leadership position within an organization to enhance teamwork has been previously referred to as micropolitical behavior (Burns, 1961; Blasé \& Blase, 1997; Newman, 2005; West, 1999). Hence, we refer to this additional category as micropolitical leadership orientation.

Transferring leadership dimensions to the team context. Overall, ample empirical evidence has demonstrated that leaders behaving in the ways consistent with orientations described above tend to lead the team to higher performance (Bass, 1990; Bono \& Anderson, 2005; Burns, 1961; Morgeson et al., 2010; Yukl et al., 2002). Evidence also shows that the same leadership behavior could be effective when shared by the team (Pearce \& Sims, 2002), possibly even exceeding the effectiveness of vertical leadership (Ensley et al., 2006; Pearce \& Sims, 2002; Wang et al., 2014).

We assert that the described leadership behaviors may profit from the involvement of team members. For example, research on teamwork has produced comparable findings to the research on task-oriented and relationoriented behaviors in leadership studies (e.g., Anderson \& West, 1996; Kauffeld \& Frieling, 2001; West, 2012). West (2012) stated that team members from well-functioning teams were able to reflect on both their team tasks (task reflexivity; e.g., being able to focus on their tasks and objectives) and their social environment (social reflexivity; e.g., being able to support each other and care for an overall positive emotional climate). In other studies, not only the team leader but also team members encouraged innovational thinking and implemented new ideas to enhance team effectiveness (Anderson \& West, 1996; Binnewies, Ohly, \& Niessen, 2008; Hoon Song, Kolb, Hee Lee, \& Kyoung Kim, 2012). Similarly, findings on the individual use of personal internal and external networks to facilitate team work (e.g., Blaschke, Schoeneborn, \& Seidl, 2012; Joshi, 2006; Wolff \& Moser, 2009) are consistent with the shared leadership approach.

Moreover, each dimension clearly describes observable behaviors, focusing on what leaders or team members must do rather than how they ought to be to be effective (Shuck \& Herd, 2012; Yukl \& van Fleet, 1992), which matches the conceptualization of shared leadership as a dynamic team process (Hoch et al., 2010b). 


\section{Study 1: Scale Development, Item Selection, and Exploration of SPLIT's Factor Structure and Scale Reliability}

After reviewing the literature, we considered the described dimensions of task, relation, change, and micropolitical leadership orientation as especially suitable for assessing shared leadership in teams, because the four dimensions are drawn from leadership research but similar findings appear in team research. Moreover, the dimensions cover a broad variety of leadership behaviors, including long-term recognizable task- and relationorientation, as well as behavior especially relevant to modern work life, change-oriented leadership, and networking activities. Collectively, these behaviors go beyond those described in specific leadership theories, such as the theory on transformational leadership (Small \& Rentsch, 2010). Therefore, we decided to include shared task, relation, change, and micropolitical leadership orientation as four shared leadership dimensions into SPLIT. As previous studies have shown, these different leadership behaviors are not completely independent (Yukl et al., 2002; Judge et al., 2004) and are therefore assumed to represent an overall higher-order shared leadership dimension.

The purpose of the first study is to provide evidence for the construct validity of a four-factor model of shared leadership. As a first step in this process, items representing the four dimensions are developed. Hence, confirmatory factor analysis is expected to confirm that our theoretical model provides good fit to the data. The factor structure is assumed to remain robust even when testing for common method bias. Scale reliability as well as preliminary findings on the factors' convergent and discriminant validity are expected to further support the factor structure of SPLIT.

\subsection{Method}

Instrumentation and item development. Given that no existing validated questionnaire simultaneously assesses all four leadership dimensions, we developed a new questionnaire drawing on existing scale items that represent aspects of the different dimensions. Items that assess task, relation, and change leadership orientation were adapted from Yukl, Gordon and Taber (2002), and items that tap aspects representing micropolitical leadership orientation were adapted from work from Burns (1961), Morgeson, DeRue and Karam (2010), and Wolff and Moser (2009). An expert group consisting of the authors and researchers specialized in teamwork and leadership studies with university degrees in psychology selected items from the two studies that were judged to assess aspects of the dimensions in a team context. Item development was then conducted in several steps. First, on the basis of the selected items, new items in German were created and rewritten to assess the shared leadership aspect. Following the approach by other researchers (Avolio et al., 2003; Hiller et al., 2006), a referent-shift consensus model was used in which team members assessed perceptions of their team's shared leadership (Chan, 1998). Second, items were presented to an expert panel consisting of scholars and consultants who discussed which items best represented the four leadership dimensions, the items in need of refinement, and the addition of items that represented missing aspects. Third, the resulting set of 84 items was presented to a heterogeneous group of 100 participants to assess content validity and item comprehensibility. Participants answered all items on a 6-point Likert-type scale ranging from $0 \%$ (“does not apply at all”) to $100 \%$ (“fully applies”). Based on an item analysis, the expert team rank-ordered the items according to importance and several items were excluded. Finally, a selection of 30 items best representing the four dimensions was agreed upon.

Sampling procedure. Solicitation for participation was achieved using a snowball method of data collection. Participants were addressed via internet (i.e., by contacting friends, family and colleagues via e-mail and social media) as well as directly on symposia and public events. About 100 individual e-mails and 10 e-mails using distribution lists and internet forums were distributed asking the recipients to forward these entries to their contacts. The invitation text stipulated that people who 1) were working in teams consisting of at least three members, 2) were not officially assigned a specific leadership position, and 3) whose companies were located in Germany could participate. No constraints were placed on type of profession, the industrial sector, or size of enterprise. In the invitation text, participants were provided with a link to an online survey available for three months. To control for duplicate entries, a personal code was generated prior to participation.

Participant characteristics. In total, 352 participants responded. Due to the described data collection procedure we were not able to report an exact response rate. On average, participants were 30 years old $(M=30.35$, $S D=10.72)$. The sample consisted of $42.0 \%$ males and $54.1 \%$ females $(4.0 \%$ did not specify gender). From a wide variety of fields, the largest number worked in the services (52.9\%), the social (31.5\%), and the industrial 
sector (8.5\%). Seventeen percent had been working in their teams for more than five years, $44.9 \%$ for more than one year, and $37.5 \%$ for less than a year. Descriptive statistics for the sample demographics are displayed in Table 1.

Measures. Participants responded to the initial 30-item version of SPLIT on a 6-point Likert-type scale ranging from $0 \%$ ("does not apply at all”) to $100 \%$ ("fully applies") in steps of 20 . They were instructed to think about their team members and not their official team leader while answering the questions. This instruction was intended to minimize the unintended effect of a team member providing information about vertical leadership rather than shared leadership within the team.

Statistical analyses. First, item characteristics (item difficulties and factor loadings) were examined. Given that our model was grounded on a theoretical factor structure, we conducted confirmatory factor analysis (CFA; Crowley \& Fan, 1997) using MPlus version 7 (Muthén \& Muthén, 2012). First, we examined a correlated fourfactor model to evaluate whether preconditions were met in support of our assumed higher-order model (Marsh, Hau, \& Wen, 2004). As recommended in Byrne (2012), we applied multiple criteria by assessing the ratio of $\chi^{2}$ to degrees of freedom $(d f)$, Root Mean Square Error of Approximation (RMSEA), Standardized Root Mean Square residual (SMRM) and Comparative Fit Index (CFI). We then examined factor loadings and structure coefficients (Graham, Guthrie, \& Thompson, 2003). Hence, assessing the Bayesian information criterion (BIC) difference for non-nested models (Raftery, 1995), the correlated four-factor model was compared to a model including one common second-order factor representing overall shared leadership. To account for possible common method bias in the data, we also assessed model fit with a single factor model. This analysis evaluated whether the proposed four first-order factor structure with one second-order factor was superior to a model explaining all variance by a single factor (Byrne, 2012). As a more rigorous means of assessing common method bias, we also ran a fourth CFA on a model including a latent method factor for all manifest indicators (Podsakoff, MacKenzie, Lee, \& Podsakoff, 2003). If factor structure and model fit remain intact this further strengthens internal validity (Johnson, Rosen, \& Djurdjevic, 2011). All four CFA models tested in this study are displayed in Figure 1.

Scale internal consistency (Cronbach's alpha), composite reliabilities, and the average variance extracted (AVE), as the amount of variance captured by a factor in relation to variance from random measurement error, were calculated to assess internal reliability (Hair, Black, Babin, \& Anderson, 2009). To further explore discriminant validity, we evaluated whether each factor's AVE exceeded its squared correlation estimate with any other factor (Fornell \& Larcker, 1981; Hair et al., 2009) and whether confidence intervals ( \pm 2 SE) around the correlation estimates excluded 1.0 (Anderson \& Gerbing, 1988; Martínez Caro \& Martinez Garcia, 2007). All reported $p$-values are two-tailed with the significance level set at 0.05 .

\begin{tabular}{|c|c|c|c|c|c|c|c|c|c|c|c|c|}
\hline & \multicolumn{3}{|c|}{ Study $1(N=352)$} & \multicolumn{3}{|c|}{ Study $2(N=404)$} & \multicolumn{3}{|c|}{$\begin{array}{l}\text { Study } 2 \text { subsample } 1 \\
(n=201)\end{array}$} & \multicolumn{3}{|c|}{$\begin{array}{l}\text { Study } 2 \text { subsample } 2 \\
(n=203)\end{array}$} \\
\hline & $\%$ & Mean & $S D$ & $\%$ & Mean & $S D$ & $\%$ & Mean & $S D$ & $\%$ & Mean & $S D$ \\
\hline Age & & 30.35 & 10.72 & & 38.46 & 12.43 & & 38.21 & 13.39 & & 38.68 & 11.54 \\
\hline Females & $42.00^{1}$ & & & $58.42^{2}$ & & & $63.18^{3}$ & & & $53.69^{4}$ & & \\
\hline \multicolumn{13}{|l|}{ Sectors } \\
\hline Services & 52.90 & & & 39.60 & & & 40.80 & & & 38.42 & & \\
\hline Social & 31.50 & & & 35.15 & & & 32.84 & & & 37.44 & & \\
\hline Industrial & 8.50 & & & 12.13 & & & 8.50 & & & 15.76 & & \\
\hline Others & 7.10 & & & 13.11 & & & 17.91 & & & 8.37 & & \\
\hline \multicolumn{13}{|l|}{ Tenure } \\
\hline$<1$ year & 37.50 & & & 27.23 & & & 26.37 & & & 28.08 & & \\
\hline 1 - 5 years & 44.90 & & & 39.36 & & & 41.79 & & & 36.94 & & \\
\hline >5 years & $17.00^{4}$ & & & $32.67^{5}$ & & & $30.84^{6}$ & & & 34.48 & & \\
\hline
\end{tabular}

Note: ${ }^{1}$ Missing data: 4.00\%; ${ }^{2}$ missing data: 6.68\%; ${ }^{3}$ missing data: $12.44 \%$; ${ }^{4}$ missing data: $1.00 \%$; ${ }^{4}$ missing data: $0.60 \%$; ${ }^{5}$ missing data: $0.74 \%$; ${ }^{6}$ missing data: $1.00 \%$. 


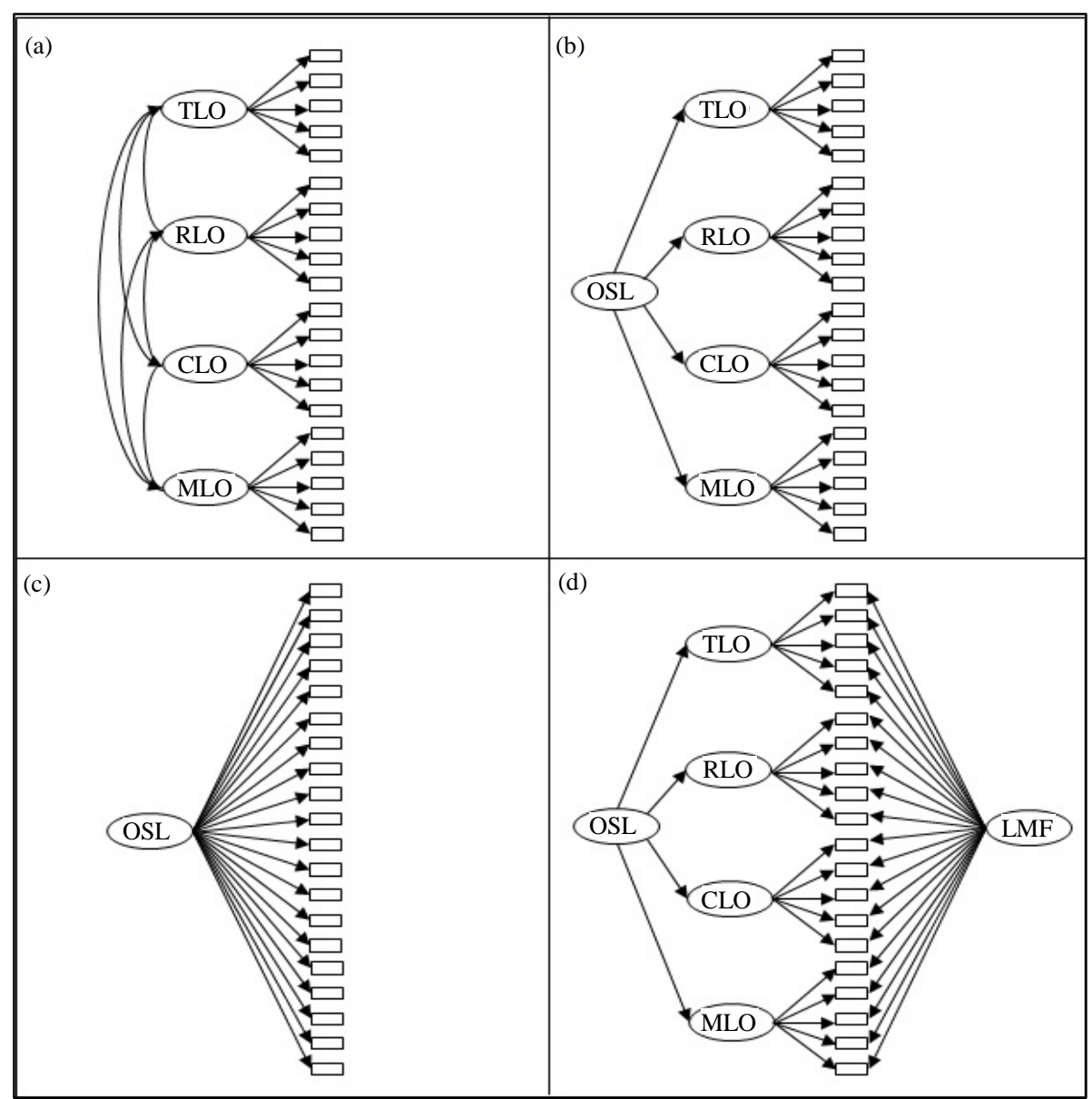

Figure 1. CFA models with 20 items in a sample of $n=352$ (error terms are not depicted) for (a) a correlated four-factor model, (b) a second-order model, (c) a single-factor model and (d) a second-order model including a latent method factor. TLO = task leadership orientation; RLO = relation leadership orientation; CLO = change leadership orientation; MLO = micropolitical leadership orientation; OSL = overall shared leadership; LMF = latent method factor.

\subsection{Results}

Item analysis. An item analysis was conducted on all 30 items. Analyzing item difficulty led to the exclusion of two items lying outside the cut-off values suggested in the literature (e.g., Stöber, 2001). We had clear hypotheses about the factor structure. Thus, we examined factor loadings for each item on the corresponding factor. All items loaded significantly and most highly $(>0.50)$ on the scales they were supposed to represent apart from two items which were eliminated (Chan, 1998; Grohmann \& Kauffeld, 2013). Furthermore, items loading highly on several factors with small loading distances to other factors resulted in the exclusion of three items (Kauffeld, Jonas, Grote, Frey, \& Frieling, 2004; Costello \& Osborne, 2005). To achieve a balanced number of items across the four scales, three additional items with the lowest factor loadings or judged to fit least with the other item content were eliminated (Shrout \& Yager, 1989). This led to a final set of 20 items with five items representing each scale. Means and standard deviations of all items are displayed in Table 2.

CFA, pattern and structure coefficients. Model fit for CFA on the final set of 20 items was assessed according to cut-offs proposed in the literature: RMSEA and SMRM less than 0.08 and a CFI greater than 0.90 indicate an acceptable model fit (Wang \& Wang, 2012). Model fit for all CFA conducted in this study are displayed in Table 3.

The first analysis revealed that the correlated four-factor solution fit the data well. Correlations between the factors were significant, varying from 0.53 and 0.83 . The pattern structures revealed that items highly loaded on the factors that they were supposed to represent. The structure coefficients also displayed the expected pattern. 
Table 2. Items, means and standard deviations for SPLIT.

\begin{tabular}{|c|c|c|}
\hline & Mean & $S D$ \\
\hline \multicolumn{3}{|l|}{ Task leadership orientation } \\
\hline 1) As a team we clearly assign tasks. & 76.65 & 21.85 \\
\hline 2) As a team we clearly communicate our expectations. & 68.15 & 23.87 \\
\hline 3) As a team we provide each other with work relevant information. & 71.45 & 24.09 \\
\hline 4) As a team we ensure that everyone knows their tasks. & 78.52 & 22.34 \\
\hline 5) As a team we monitor goal achievement. & 70.00 & 26.75 \\
\hline \multicolumn{3}{|l|}{ Relation leadership orientation } \\
\hline 1) As a team we take sufficient time to address each other's concerns. & 72.71 & 22.51 \\
\hline 2) As a team we recognize good performance. & 73.35 & 28.87 \\
\hline 3) We promote team cohesion. & 73.62 & 24.62 \\
\hline 4) We support each other in handling conflicts within the team. & 72.74 & 24.29 \\
\hline 5) As a team we never let each other down. & 76.14 & 23.12 \\
\hline \multicolumn{3}{|l|}{ Change leadership orientation } \\
\hline 1) We help each other to correctly understand ongoing processes in our team. & 77.27 & 19.32 \\
\hline 2) As a team we help each other to learn from past events. & 76.46 & 20.68 \\
\hline 3) As a team we help each other to correctly understand current company events. & 76.16 & 20.96 \\
\hline 4) As a team we can inspire each other for ideas. & 71.40 & 21.75 \\
\hline 5) As a team we support each other with the implementation of ideas. & 73.68 & 22.47 \\
\hline \multicolumn{3}{|l|}{ Micropolitical leadership orientation } \\
\hline 1) We use networks in order to support our team's work. & 58.45 & 33.49 \\
\hline 2) We ensure that our team is supported with necessary resources to fulfill the task. & 76.03 & 23.75 \\
\hline 3) As a team we assist each other to network. & 63.67 & 28.17 \\
\hline 4) We establish contact with important experts valuable for our team. & 60.81 & 32.21 \\
\hline 5) As a team we are open to external assistance in the case of internal team problems. & 71.29 & 27.95 \\
\hline
\end{tabular}

Table 3. CFA results from Study 1.

\begin{tabular}{lccccc}
\hline \multicolumn{1}{c}{ Model } & $\chi^{2}$ & $d f$ & RMSEA & CFI & SRMR \\
\hline Correlated four-factor model & 319.49 & 164 & 0.05 & 0.94 & 0.05 \\
Second-order factor model & 320.70 & 166 & 0.05 & 0.94 & 0.05 \\
Single factormodel & 722.00 & 170 & 0.10 & 0.79 & 0.08 \\
Second-order factor model including a latent method factor & 234.40 & 146 & 0.05 & 0.95 & 0.05 \\
\hline
\end{tabular}

Each item had a higher structure coefficient for the latent factor on which its pattern coefficient was freely estimated than for any of the other factors for which its pattern coefficient was constrained to zero (Glanville \& Wildhagen, 2007; Graham et al., 2003). Both pattern and structure coefficients are displayed in Table 4.

The high correlations between the factors also strengthen the appropriateness of assuming an underlying second-order factor (Thompson, 2005). Model fit for a model with four first-order factors and one common second-order factor was similar to the correlated first-order factor. All factors loaded significantly on the second-order factor with loadings from 0.70 to 0.90 . The BIC difference $(0.00)$ indicated nonsignificant differences between the two models. Following the principle of parsimony, the second-order factor model therefore is the preferable model. As expected, a model with just one overall first-order factor did not provide acceptable model fit, showing that covariance across the measure could not be explained by one single factor. Furthermore, model fit and factor structure of the four first-order factors and the second-order factor remained robust even when including a latent method factor on which all manifest items loaded, providing further evidence for the model's internal validity. 
Table 4. Standardized pattern and structure coefficients for the first-order latent variables in Study 1 and 2.

\begin{tabular}{|c|c|c|c|c|c|c|c|c|c|c|c|c|c|c|c|c|}
\hline \multirow[b]{3}{*}{ Item } & \multicolumn{4}{|c|}{ ALO } & \multicolumn{4}{|c|}{ BLO } & \multicolumn{4}{|c|}{ CLO } & \multicolumn{4}{|c|}{ MLO } \\
\hline & \multicolumn{2}{|c|}{ Study 1} & \multicolumn{2}{|c|}{ Study 2} & \multicolumn{2}{|c|}{ Study 1} & \multicolumn{2}{|c|}{ Study 2} & \multicolumn{2}{|c|}{ Study 1} & \multicolumn{2}{|c|}{ Study 2} & \multicolumn{2}{|c|}{ Study 1} & \multicolumn{2}{|c|}{ Study 2} \\
\hline & $p$ & $r_{s}$ & $p$ & $r_{s}$ & $p$ & $r_{s}$ & $p$ & $r_{s}$ & $p$ & $r_{s}$ & $p$ & $r_{s}$ & $p$ & $r_{s}$ & $p$ & $r_{s}$ \\
\hline 1 & 0.66 & 0.66 & 0.69 & 0.69 & 0.00 & 0.54 & 0.00 & 0.54 & 0.00 & 0.52 & 0.00 & 0.61 & 0.00 & 0.36 & 0.00 & 0.40 \\
\hline 2 & 0.76 & 0.76 & 0.85 & 0.85 & 0.00 & 0.51 & 0.00 & 0.57 & 0.00 & 0.54 & 0.00 & 0.60 & 0.00 & 0.34 & 0.00 & 0.43 \\
\hline 3 & 0.74 & 0.74 & 0.73 & 0.73 & 0.00 & 0.58 & 0.00 & 0.61 & 0.00 & 0.54 & 0.00 & 0.60 & 0.00 & 0.40 & 0.00 & 0.49 \\
\hline 4 & 0.74 & 0.74 & 0.72 & 0.72 & 0.00 & 0.57 & 0.00 & 0.59 & 0.00 & 0.57 & 0.00 & 0.58 & 0.00 & 0.38 & 0.00 & 0.45 \\
\hline 5 & 0.56 & 0.56 & 0.60 & 0.60 & 0.00 & 0.52 & 0.00 & 0.58 & 0.00 & 0.56 & 0.00 & 0.61 & 0.00 & 0.35 & 0.00 & 0.41 \\
\hline 6 & 0.00 & 0.47 & 0.00 & 0.48 & 0.77 & 0.77 & 0.78 & 0.78 & 0.00 & 0.61 & 0.00 & 0.76 & 0.00 & 0.43 & 0.00 & 0.50 \\
\hline 7 & 0.00 & 0.54 & 0.00 & 0.59 & 0.73 & 0.73 & 0.81 & 0.81 & 0.00 & 0.63 & 0.00 & 0.75 & 0.00 & 0.40 & 0.00 & 0.53 \\
\hline 8 & 0.00 & 0.52 & 0.00 & 0.51 & 0.82 & 0.82 & 0.87 & 0.87 & 0.00 & 0.63 & 0.00 & 0.75 & 0.00 & 0.47 & 0.00 & 0.61 \\
\hline 9 & 0.00 & 0.52 & 0.00 & 0.51 & 0.81 & 0.81 & 0.84 & 0.84 & 0.00 & 0.67 & 0.00 & 0.73 & 0.00 & 0.45 & 0.00 & 0.55 \\
\hline 10 & 0.00 & 0.39 & 0.00 & 0.42 & 0.74 & 0.74 & 0.83 & 0.83 & 0.00 & 0.66 & 0.00 & 0.76 & 0.00 & 0.41 & 0.00 & 0.51 \\
\hline 11 & 0.00 & 0.47 & 0.00 & 0.49 & 0.00 & 0.64 & 0.00 & 0.69 & 0.73 & 0.73 & 0.85 & 0.85 & 0.00 & 0.43 & 0.00 & 0.51 \\
\hline 12 & 0.00 & 0.54 & 0.00 & 0.60 & 0.00 & 0.61 & 0.00 & 0.72 & 0.76 & 0.76 & 0.84 & 0.84 & 0.00 & 0.40 & 0.00 & 0.54 \\
\hline 13 & 0.00 & 0.53 & 0.00 & 0.52 & 0.00 & 0.69 & 0.00 & 0.76 & 0.76 & 0.76 & 0.85 & 0.85 & 0.00 & 0.48 & 0.00 & 0.62 \\
\hline 14 & 0.00 & 0.53 & 0.00 & 0.52 & 0.00 & 0.68 & 0.00 & 0.75 & 0.80 & 0.80 & 0.82 & 0.82 & 0.00 & 0.45 & 0.00 & 0.54 \\
\hline 15 & 0.00 & 0.40 & 0.00 & 0.43 & 0.00 & 0.62 & 0.00 & 0.73 & 0.79 & 0.79 & 0.85 & 0.85 & 0.00 & 0.41 & 0.00 & 0.52 \\
\hline 16 & 0.00 & 0.35 & 0.00 & 0.40 & 0.00 & 0.48 & 0.00 & 0.56 & 0.00 & 0.46 & 0.00 & 0.61 & 0.68 & 0.68 & 0.69 & 0.69 \\
\hline 17 & 0.00 & 0.41 & 0.00 & 0.49 & 0.00 & 0.45 & 0.00 & 0.58 & 0.00 & 0.47 & 0.00 & 0.61 & 0.64 & 0.64 & 0.74 & 0.74 \\
\hline 18 & 0.00 & 0.39 & 0.00 & 0.42 & 0.00 & 0.52 & 0.00 & 0.62 & 0.00 & 0.47 & 0.00 & 0.61 & 0.76 & 0.76 & 0.84 & 0.84 \\
\hline 19 & 0.00 & 0.40 & 0.00 & 0.42 & 0.00 & 0.51 & 0.00 & 0.61 & 0.00 & 0.50 & 0.00 & 0.59 & 0.72 & 0.72 & 0.77 & 0.77 \\
\hline 20 & 0.00 & 0.30 & 0.00 & 0.35 & 0.00 & 0.46 & 0.00 & 0.60 & 0.00 & 0.49 & 0.00 & 0.61 & 0.65 & 0.65 & 0.71 & 0.71 \\
\hline
\end{tabular}

Note TLO = task leadership orientation; RLO = relation leadership orientation; CLO = change leadership orientation; MLO = micropolitical leadership orientation; $p=$ pattern coefficient, $r_{s}=$ structure coefficient.

Reliability. Internal consistency was high for all four first-order factors and the second-order factor $(\alpha>$ 0.80). Composite reliability scores for all factors were also above the commonly used cut-off scores of 0.70 (Hair et al., 2009; Fornell \& Larcker, 1981), ranging from 0.73 to 0.84. Hair, Black, Babin and Anderson (2009) also recommended a cut-off of 0.50 for AVE estimates. All factors except the factor representing the dimension micropolitical leadership orientation (0.49) were above the cut-off. Results of the scale internal consistencies, composite reliabilities, and the AVE estimates are displayed in Table 5.

Discriminant validity. Despite the common second-order factor explaining variance in all first-order factors, we evaluated whether factors discriminated from one another. Each factor's AVE was larger than the squared correlation estimates between factors, except for the factors of relation and change leadership orientation. However, given that the confidence interval ( $\pm 2 \mathrm{SE}$ ) around the correlation estimates between the two factors never reached 1.0, there is still evidence that the two factors discriminate from one another to some extent (Anderson \& Gerbing, 1988; Martínez Caro \& Martinez Garcia, 2007).

\section{Study 2: Model Replication and Validation}

The purpose of Study 2 is the replication of the factor structure theoretically derived and confirmed in Study 1 in an independent sample. Focus of Study 2 is hence to further evaluate convergent and criterion validity of SPLIT.

Confirmatory factor analysis is expected to re-confirm the factor structure. Scale reliabilities are expected to be high. Proving for convergent validity, it is assumed that all factors correlate with factors derived from another questionnaire assessing shared leadership. Concerning SPLIT's criterion validity, all of its factors are believed to correlate with variables closely related to shared leadership-perceived autonomy, de-centralization and performance (Wegge et al., 2010; Pearce \& Sims, 2002; further described in the method section). Furthermore, the scales are tested for consistency across different industrial sectors. 
Table 5. Cronbach's alphas, composite reliabilities, average variance extracted, means and standard deviations for SPLIT’s latent factors.

\begin{tabular}{|c|c|c|c|c|c|c|c|c|c|c|}
\hline \multirow[b]{2}{*}{ Scales } & \multicolumn{5}{|c|}{ Study $1(N=352)$} & \multicolumn{5}{|c|}{ Study $2(N=404)$} \\
\hline & $\alpha$ & $C R$ & $A V E$ & Mean & $S D$ & $\alpha$ & $C R$ & $A V E$ & Mean & $S D$ \\
\hline TLO & 0.81 & 0.73 & 0.50 & 74.99 & 17.36 & 0.84 & 0.75 & 0.52 & 74.12 & 19.73 \\
\hline RLO & 0.88 & 0.80 & 0.60 & 73.75 & 19.52 & 0.91 & 0.84 & 0.68 & 69.83 & 22.32 \\
\hline CLO & 0.88 & 0.76 & 0.55 & 75.00 & 17.25 & 0.93 & 0.85 & 0.71 & 71.03 & 21.14 \\
\hline MLO & 0.82 & 0.73 & 0.49 & 66.06 & 22.30 & 0.86 & 0.78 & 0.56 & 64.65 & 23.90 \\
\hline OSL & 0.86 & 0.84 & 0.68 & 75.55 & 16.76 & 0.88 & 0.86 & 0.73 & 71.20 & 19.44 \\
\hline
\end{tabular}

Note. $\alpha=$ Cronbach's alpha; $C R=$ Composite Reliability; $A V E=$ Average Variance Extracted; $S D=$ Standard Deviation; TLO = task leadership orientation; RLO = relation leadership orientation; CLO = change leadership orientation; MLO = micropolitical leadership orientation; OSL = overall shared leadership.

\subsection{Method}

Sampling procedure. Data collection was similar to the procedure in Study 1. About 250 individual e-mails and seven e-mails using distribution lists and internet forums were distributed. Inclusion criteria were identical to those in Study 1. Only recipients who had not participated in Study 1 could participate. Participants were provided with a link to an online survey available for an extended four-month period (due to public holidays).

Participant characteristics. The final sample consisted of $N=404\left(M_{A G E}=38.45, S D=12.42\right)$; $34.9 \%$ were males and $58.4 \%$ females (6.7\% did not provide information about gender). The majority worked in the services (39.6\%) and social sector (35.2\%), and a smaller number worked in the industrial sector (12.13\%). The majority had been working on their team for more than a year $(72.0 \%)$. Two subsamples were selected $\left(n_{1}=201\right)$ for the evaluation of convergent validity and $\left(n_{2}=203\right)$ for the evaluation of criterion validity. Descriptive statistics for the total and subsample demographics are displayed in Table 1.

Measures. For all measures we applied a 6-point Likert-type scale ranging from $0 \%$ (“does not apply at all”) to $100 \%$ ("fully applies"). Cronbach's alphas, means, and standard deviations found in our data are displayed in Table 6.

Shared Leadership Questionnaire (SLQ). For the subsample of $n_{1}=201$, we included the Shared Leadership Questionnaire (SLQ) developed by Hoch, Duhlebohn and Pearce (2010a). This instrument has already been successfully used in other studies (Hoch et al., 2010b). Items were obtained through personal communication. The SLQ consists of 20 items in German, measuring shared leadership with regard to the leadership styles of transformational leadership, directive/participative leadership, transactional leadership, aversive leadership and individual and team empowerment (example item: "My team members encourage me to go above and beyond what is normally expected of one").

The SLQ is based on a different leadership model than SPLIT, and its six scales differ from SPLIT's four dimensions. However, there are some behavioral aspects that can be identified in both. For example, envisioning change is part of transformational and change-oriented leadership; providing appreciation and feedback for achievements can be represented by aspects of transactional and relation-oriented leadership; self-development is represented by some aspects of empowerment and relation-oriented leadership. Other aspects such as task assignments (task leadership orientation), coherence and conflict resolution (relation leadership orientation), learning from past experiences (change leadership orientation), and networking and resource allocation (micropolitical leadership orientation) are emphasized in SPLIT to a greater extent. To date, research has not yet clearly identified parallels and confinements of different leadership models (Judge et al., 2004; Yukl et al., 2002). Nevertheless, we assumed that shared leadership assessed with the SLQ should still be positively correlated to SPLIT's shared leadership scales.

To evaluate criterion validity in the second subsample of $n_{2}=203$ participants, we included the following three scales.

Centralization. The German translation of the centralization scale from Aiken and Hage (1968) by Barisch (2011) consists of five items measuring the degree to which power in a team or an organization is centralized on one individual (example item: "There can be little action taken here until a supervisor approves of a decision"). High scores represent high degrees of centralization and should therefore be negatively related to shared leadership (Wegge et al., 2010). 
Table 6. Means, standard deviations, Cronbach’s alphas and bivariate pearson correlations for all measures in Study 2.

\begin{tabular}{|c|c|c|c|c|c|c|c|c|c|c|c|c|c|c|c|}
\hline Scale & Mean & $S D$ & 1 & 2 & 3 & 4 & 5 & 6 & 7 & 8 & 9 & 10 & 11 & 12 & 13 \\
\hline 1) TLO & 74.12 & 19.73 & $0.84^{* *}$ & & & & & & & & & & & & \\
\hline 2) RLO & 69.83 & 22.32 & $0.64^{* *}$ & $0.91^{* *}$ & & & & & & & & & & & \\
\hline 3) $\mathrm{CLO}$ & 71.03 & 21.14 & $0.67^{* *}$ & $0.82^{* *}$ & $0.93^{* *}$ & & & & & & & & & & \\
\hline 4) $\mathrm{MLO}$ & 64.65 & 23.90 & $0.50^{* *}$ & $0.65^{* *}$ & $0.66^{* *}$ & $0.86^{* *}$ & & & & & & & & & \\
\hline 5) Transformational & 64.40 & 22.58 & $0.56^{* *}$ & $0.66^{* *}$ & $0.63^{* *}$ & $0.67^{* *}$ & $0.76^{* *}$ & & & & & & & & \\
\hline 6) Participative & 65.44 & 25.05 & $0.56^{* *}$ & $0.53^{* *}$ & $0.55^{* *}$ & $0.49^{* *}$ & $0.62^{* *}$ & $0.86^{* *}$ & & & & & & & \\
\hline 7) Transactional & 53.35 & 23.12 & $0.37^{* *}$ & $0.42^{* *}$ & $0.42^{* *}$ & $0.44^{* *}$ & $0.57^{* *}$ & $0.53^{* *}$ & $0.67^{* *}$ & & & & & & \\
\hline 8) Individual Empowerment & 68.03 & 25.11 & $0.44^{* *}$ & $0.51^{* *}$ & $0.53^{* *}$ & $0.42^{* *}$ & $0.57^{* *}$ & $0.41^{* *}$ & $0.57^{* *}$ & $0.87^{* *}$ & & & & & \\
\hline 9) Team Empowerment & 75.27 & 19.20 & $0.49^{* *}$ & $0.46^{* *}$ & $0.53^{* *}$ & $0.39^{* *}$ & $0.52^{* *}$ & $0.46^{* *}$ & $0.42^{* *}$ & $0.51^{* *}$ & $0.70^{* *}$ & & & & \\
\hline 10) Aversive & 6.29 & 15.86 & $-0.23^{* *}$ & ${ }^{*}-0.21^{* *}$ & $-0.18^{* *}$ & $-0.19^{* *}$ & -0.10 & $-0.21^{* *}$ & $0.03^{* *}$ & $-0.12^{* *}$ & -0.08 & $0.86^{*}$ & & & \\
\hline 11) Centrality ${ }^{3}$ & 39.57 & 25.76 & $-0.20^{*}$ & $-0.23^{*}$ & $-0.19^{*}$ & $-0.27^{*}$ & - & - & - & - & - & - & 0.90 & & \\
\hline 12) Autonomy ${ }^{3}$ & 63.91 & 26.00 & $0.33^{* *}$ & $0.32^{* *}$ & $0.28^{* *}$ & $0.42^{* *}$ & - & - & - & - & - & - & $-0.40^{* *}$ & $0.88^{*}$ & \\
\hline 13) Team Performance ${ }^{3}$ & 65.46 & 19.91 & $0.57^{* *}$ & $0.53^{* *}$ & $0.54^{* *}$ & $0.50^{* *}$ & - & - & - & - & - & - & $-0.19^{* *}$ & $0.40^{* *}$ & 0.83 \\
\hline
\end{tabular}

Note: $N=404 ;{ }^{* *} p<0.01 ;{ }^{*} p<0.05$; Cronbach's alpha in the diagonal; ${ }^{1} \mathrm{SLQ}=$ Shared Leadership Questionnaire overall score; ${ }^{2}$ correlations rely on a subsample of $n_{1}=201{ }^{3}$ correlations rely on a subsample of $n_{2}=203$; TLO = task leadership orientation; RLO = relation leadership orientation; CLO = change leadership orientation; $\mathrm{MLO}=$ micropolitical leadership orientation; OSL = overall shared leadership.

Autonomy. We assessed autonomy with a three-item scale from the Job Diagnostic Survey (Hackman \& Oldham, 1975) using the German version (Schmidt \& Kleinbeck, 1999). An example item is: "The job gives me considerable opportunity for independence and freedom in how I do the work.” High scores indicate high degrees of autonomy and were expected to be positively related to shared leadership (Wegge et al., 2010).

Team performance. Team performance was measured with six items adapted from Kirkman and Rosen (1999) using the German version developed by Lehmann-Willenbrock, Grohmann and Kauffeld (2011). An example item is: “As a team, we meet our quantitative and qualitative goals.” High scores indicate high team performance and are assumed to be positively related to shared leadership (e.g., Ensley et al., 2006; Hoch \& Duhlebohn, 2013; Pearce \& Sims, 2002; Wegge et al., 2010).

Psychometric analyses. To reconfirm the factor structure with four first-order factors and one second-order factor posited and confirmed in Study 1, we conducted CFA in the total sample on $N=404$. The same procedures in Study 1 to evaluate scale reliability and discriminant validity between the scales were undertaken, applying the same cut-off criteria. Pearson correlation coefficients were calculated to assess convergent validity with the SLQ for a subsample of $n_{1}=201$. Pearson correlation coefficients were also calculated to assess criterion validity for a subsample of $n_{2}=203$ participants. Multivariate analysis of variance (MANOVA) on the total sample was performed to test scale consistency across different industrial sectors.

\subsection{Results}

CFA, pattern, and structure coefficients. CFA replicated a good model fit for the second-order model $\left(\chi^{2}=\right.$ 380.06, $d f=166$, RMSEA $=0.06$, CFI $=0.95$, SRMR=0.05). Items loaded highly on the factors which they were supposed to represent with factor loadings varying from 0.60 and 0.87 and each item showed the highest structure coefficient with its theoretical first-order factor (see Table 4). All first-order factors loaded significantly on the second-order factor with loadings from 0.75 and 0.95 .

Reliability. Internal consistencies, composite reliabilities, and the AVE estimates are shown in Table 5. For all of SPLIT scales, Cronbach's alphas ranged from good to excellent (0.84 - 0.93), and alpha was good for SPLIT's second-order shared leadership score (0.88). Indicators for composite reliabilities were also high for all scales $(0.75$ - 0.85). All AVE estimates exceeded the cut-off value of 0.50 with values ranging from 0.52 to 0.71 .

Discriminant validity. The comparison between the AVE estimates and the factor correlation estimates revealed a high degree of shared variance between the two dimensions of relation and change leadership orientation. However, the confidence intervals of correlation estimates never included 1.0, thus providing evidence for 
some discrimination between the factors.

Convergent and criterion validity. Correlations between the SPLIT scales and all scales for convergent and criterion validity are presented in Table 6. In line with our expectations, moderate correlations between all scales of SPLIT and the SLQ scales were significant, confirming convergent validity. Furthermore, as expected, all scales from SPLIT correlated moderately but significantly and negatively with centrality scores and significantly and positively with autonomy and team performance, thus indicating criterion validity.

MANOVA. Finally, the MANOVA revealed no significant differences in shared leadership between different industrial sectors (Wilk’s $F(12,1179)=1.32, p=0.20)$. Univariate comparisons between the subgroups are included in Table 7.

\section{Discussion}

Facing the incongruence between increased relevance of shared leadership and the paucity of reliable, validated shared leadership instruments, we developed the Shared Professional Leadership Inventory for Teams (SPLIT). Based on the review of relevant literature, our instrument was intended to measure four dimensions representing a broad variety of shared leadership behaviors that can be shared in teams: task, relation, change, and micropolitical leadership orientation. In a multi-step process, 20 items were selected to measure the four dimensions. Rigorous confirmatory factor analyses confirmed the hypothesized model with four first-order factors and a common second-order factor with high factor loadings even when controlling for possible common method bias. Internal scale consistencies were high. Robustness of our findings could be shown by applying SPLIT to an independent second sample, in which the hypothesized model, again with very high internal consistencies, could be reconfirmed. Results suggested that SPLIT is an adequate, concise instrument for assessing shared leadership across different industrial sectors. Correlations between the factors and significant loadings on a second-order factor are consistent with the conclusion that while representing different aspects, all factors belonged to the same overall construct of shared leadership.

Furthermore, convergent validity support for SPLIT was found. All SPLIT scales were associated with the Shared Leadership Questionnaire (SLQ) scales developed by Hoch, Duhlebohn and Pearce (2010a). This support provides evidence that SPLIT measures what it was intended to measure. The moderate correlations suggest that our instrument assesses different aspects of shared leadership. One explanation could be that the SLQ relies on a different leadership model. Furthermore, some of the items included in the SLQ focus more on how team members are (e.g., "My team members are driven by higher purposes or ideals”) or how team members feel (e.g., “I feel intimidated by my team members' behavior”). SPLIT only captures observable behaviors and excludes any aspects describing characteristics or feelings, which is consistent with researchers' recommendations to clearly differentiate between behavioral aspects and leadership characteristics (Gil et al., 2005; Yukl, 1999).

We also found support for criterion validity of SPLIT. A basic assumption is that shared leadership requires at least a certain level of organizational democracy, providing employees with a certain degree of autonomy. Our findings confirm that all of SPLIT's shared leadership scales are significantly related to a scale measuring de-centralization and to a scale assessing autonomy. Additionally, the most commonly suggested positive consequence of shared leadership is improved team performance (e.g., Mehra et al., 2006; Small \& Rentsch, 2010; Pearce \& Sims, 2002). Results from Study 2 revealed positive correlations between all four shared leadership scales of SPLIT and the performance ratings assessed with the questionnaire by Kirkman and Rosen (1999), which supports SPLIT's criterion validity.

Table 7. Univariate comparison of SPLIT's scales by economic sectors.

\begin{tabular}{ccccccc}
\hline & \multicolumn{5}{c}{ Sector means } \\
\cline { 2 - 5 } & Services $(n=160)$ & Social $(n=142)$ & Industrial $(n=49)$ & Other $(n=48)$ & $F$ & $p$ \\
\hline Task leadership orientation & 74.63 & 71.32 & 77.39 & 77.00 & 1.70 & 0.17 \\
Relation leadership orientation & 68.89 & 68.32 & 73.39 & 72.92 & 1.01 & 0.39 \\
Change leadership orientation & 71.59 & 68.94 & 75.35 & 70.40 & 1.19 & 0.31 \\
Micropolitical leadership orientation & 64.11 & 62.44 & 66.47 & 69.71 & 1.23 & 0.30 \\
Overall shared leadership & 71.00 & 69.23 & 74.89 & 73.31 & 1.24 & 0.27 \\
\hline
\end{tabular}

Note: $F=$ Wilk's Lamda statistic. 


\subsection{Implications for Research and Practice}

In comparison with other shared leadership questionnaires for which first validation findings exist, SPLIT relies on a different leadership model. The instrument includes the widely accepted task- and relation-oriented leadership behaviors as well as an updated concept of change management, and its development addressed the increasing importance in networking according to researchers. Even though drawn from leadership research, the scales are considered to be particularly well-suited for the shared leadership context, because team work research has identified closely related aspects as relevant for team effectiveness. Our study provides future researchers with an instrument that not only has demonstrated scale reliability and validity in two samples of individual data but measures four major dimensions of leadership behavior that can be used in future research to assess their impact on important organization outcome variables.

SPLIT is especially suitable for practitioners because it is concise and therefore easy to use in practice. It is an instrument for human resource development practitioners to assess the degree to which employees perceive and use possibilities for participative organization of their work. SPLIT distinguishes between four major shared leadership dimensions. Thus, scale results can inform practitioners wishing to implement shared leadership in their teams by identifying shared leadership behaviors and behaviors that need to be further developed. In operations, SPLIT provides a baseline for decisions regarding job design and areas of responsibility. For example, scale results could identify which responsibilities should be further distributed across the team or which responsibilities should be more closely assigned to specific persons. Unlike leadership approaches focusing on leadership characteristics, SPLIT particularly focuses on observable behaviors. As behavior can well be modeled and developed in trainings (Grossman \& Salas, 2011; Noe, 2005), SPLIT provides an empirical base for designing training programs that focus on identifying and developing shareable leadership behaviors. Additionally, supervisory coaching and mentoring behavior can enhance employee development and performance (Clarke, 2013; Ellinger, Ellinger, \& Keller, 2003; Hui, Sue-Chan, \& Wood, 2013; Saks, Tamkin, \& Lewis, 2011) and the importance of psychometrics in planning such processes has previously been expressed (Wasylyshyn, 2003). Team managers could therefore provide coaching or mentoring to encourage the development of relevant leadership behaviors identified with SPLIT but not yet employed by team members.

\subsection{Limitations and Future Research Proposals}

Even though two studies confirmed the robustness of our findings, results are still preliminary and several limitations need to be considered. A major limitation was that we drew only from individual data. Even though a referent-shift consensus model (Chan, 1998) was used in which individuals from different teams rated leadership occurring in their team, assessing whole teams would measure shared leadership more accurately. A fully validated shared leadership instrument needs to distinguish between teams scoring high and teams scoring low on shared leadership. Multi-level confirmatory factor analyses in future studies are required to account for the nested data structure in a team sample (Goldstein, 2011). Nevertheless, the current study was able to report some important first findings for SPLIT's validity in two samples of individual data which is a first step in developing a team instrument (Mathisen, Torsheim, \& Einarsen, 2006). Similarly the development for other shared leadership scales has not yet relied on multi-level analyses but has also been an essential contribution to the shared leadership research.

Future studies are also needed to further explore SPLIT's discriminant validity. Our results indicated that relation and change leadership orientation shared a particularly large amount of variance. A particularly strong relation between those two dimensions could be discussed theoretically. For example, when team internal relationships are characterized by trust and empathy, this dynamic could facilitate an open team culture in which errors are more easily admitted and thus foster increased learning to improve as a team. These outcomes in turn are likely to further strengthen relationships within the team. Interestingly, similar aspects are also combined in the theory of transformational theory. Nevertheless, future studies are advised to explore discriminant validity by evaluating the extent to which the different factors can make independent contributions in explaining variance in relevant outcome criteria. Future studies could also further evaluate the relative predictive validity for relevant outcome criteria of SPLIT compared to shared leadership measures based on other theoretical models.

A further limitation of our study is that even though participants came from a variety of professional backgrounds and no differences across different industrial sectors were found, we only administered a German version of SPLIT to German-speaking samples. This could limit the generalizability of our results as they might 
differ in other cultural contexts (Kowske \& Anthony, 2007; Singh \& Mohanty, 2011).

\section{Conclusion}

Theoretical discussions and first empirical findings show shared leadership to be a promising concept in meeting modern work life challenges. The development of a shared leadership instrument addresses the empirical need for assessing shared leadership in teams. Initial findings on reliability and validity in two independent samples indicated that we were successful in creating a concise questionnaire that assesses four different dimensions of shared leadership. The brief number of items (20) makes the questionnaire easy to use in practice. Evaluation of psychometric criteria for our instrument on the team level is still needed, and we strongly encourage future researchers to build on our findings.

\section{References}

Agnew, C. R., Carlston, D. E., Graziano, W.G., \& Kelly, J. R. (2009). Then a Miracle Occurs: Focusing on Behavior in Social Psychological Theory and Research. New York, NY: Oxford University Press.

http://dx.doi.org/10.1093/acprof:oso/9780195377798.001.0001

Aiken, M., \& Hage, J. (1968).Organizational Interdependence and Intra-Organizational Structure. American Sociological Review, 33, 912-930. http://dx.doi.org/10.2307/2092683

Anderson, J. C., \& Gerbing, D. W. (1988). Structural Equation Modeling in Practice: A Review and Recommended Two-Step Approach. Psychological Bulletin, 103, 411-423. http://dx.doi.org/10.1037/0033-2909.103.3.411

Anderson, N., \& West, M. (1996). The Team Climate Inventory: Development of the TCI and Its Applications in Teambuilding for Innovativeness. European Journal of Work and Organizational Psychology, 5, 53-66.

http://dx.doi.org/10.1080/13594329608414840

Avolio, B. J., Bass, B. M., \& Jung, D. I. (1999). Re-Examining the Components of Transformational and Transactional Leadership Using the Multifactor Leadership. Journal of Occupational and Organizational Psychology, 72, 441-462. http://dx.doi.org/10.1348/096317999166789

Avolio, B. J., Reichard, R. J., Hannah, S. T., Walumbwa, F. O., \& Chan, A. (2009). 100 Years of Leadership Intervention Studies: A Meta-Analysis. The Leadership Quarterly, 20, 764-784. http://dx.doi.org/10.1016/j.leaqua.2009.06.006

Avolio, B. J., Sivasubramaniam, N., Murry, W. D., Jung, D., \& Garger, J. W. (2003). Development and Preliminary Validation of a Team Multifactor Leadership Questionnaire. In C. L. Pearce, \& J. A. Conger (Eds.), Shared Leadership: Reframing the Hows and Whys of Leadership (pp. 143-172). Thousand Oaks: Sage Publications. http://dx.doi.org/10.4135/9781452229539.n7

Balkundi, P., \& Kilduff, M. (2006). The Ties That Lead: A Social Network Approach to Leadership. The Leadership Quarterly, 17, 419-439. http://dx.doi.org/10.1016/j.leaqua.2006.01.001

Barisch, S. (2011). Empirische Überprüfung des Erklärungsmodells zur Optimierung der hierarchischen Teamzusammensetzung. In S. Barisch (Ed.), Optimierung von Verhandlungsteams (pp. 147-215). Wiesbaden: Gabler. http://dx.doi.org/10.1007/978-3-8349-6200-3_4

Bass, B. M. (1990). Handbook of Leadership. Theory, Research \& Managerial Applications (3rd ed.). New York, NY: Free Press.

Bergman, J. Z., Rentsch, J. R., Small, E. E., Davenport, S. W., \& Bergman, S. M. (2012). The Shared Leadership Process in Decision-Making Teams. The Journal of Social Psychology, 152, 17-42. http://dx.doi.org/10.1080/00224545.2010.538763

Binnewies, C., Ohly, S., \& Niessen, C. (2008). Age and Creativity at Work-The Interplay between Job Resources, Age and Idea Creativity. Journal of Managerial Psychology, 23, 438-457. http://dx.doi.org/10.1108/02683940810869042

Blaschke, S., Schoeneborn, D., \& Seidl, D. (2012). Organizations as Networks of Communication Episodes: Turning the Network Perspectives Inside Out. Organization Studies, 33, 297-459. http://dx.doi.org/10.1177/0170840612443459

Blase, J., \& Blase, J. (1997). The Micropolitical Orientation of Facilitative School Principals and Its Effects on Teachers' Sense of Empowerment. Journal of Educational Administration, 35, 138-164. http://dx.doi.org/10.1108/09578239710161777

Bono, J. E., \& Anderson, M. H. (2005). The Advice and Influence Networks of Transformational Leaders. Journal of Applied Psychology, 90, 1306-1314. http://dx.doi.org/10.1037/0021-9010.90.6.1306

Brass, D. J. (2001). Social Capital and Organizational Leadership. In S. J. Zaccaro, \& R. J. Klimoski (Eds.), The Nature of Organizational Leadership: Understanding the Performance Imperatives Confronting Today's Leaders (pp. 132-152). San Francisco, CA: Jossey-Bass.

Burns, J. M. (1978). Leadership. New York: Harper \& Row. 
Burns, T. (1961). Micropolitics: Mechanisms of Institutional Change. Administrative Science Quarterly, 6, 257-281. http://dx.doi.org/10.2307/2390703

Byrne, B. M. (2012). Structural Equation Modeling with Mplus: Basic Concepts, Applications, and Programming. New York, NY: Routledge.

Carson, J. B., Tesluk, P. E., \& Marrone, J. A. (2007). Shared Leadership in Teams: An Investigation of Antecedent Conditions and Performance. Academy of Management Journal, 50, 1217-1234.

Chan, D. (1998). Functional Relations among Constructs in the Same Content Domain at Different Levels of Analysis: A Typology of Composition Models. Journal of Applied Psychology, 83, 234-246. http://dx.doi.org/10.1037/0021-9010.83.2.234

Clarke, N. (2012). Evaluating Leadership Training and Development: A Levels-of-Analysis Perspective. Human Resource Development Quarterly, 23, 441-460. http://dx.doi.org/10.1002/hrdq.21146

Clarke, N. (2013). Model of Complexity Leadership Development. Human Resource Development International, 16, 135150. http://dx.doi.org/10.1080/13678868.2012.756155

Costello, A. B. \& Osborne, J. W. (2005). Best Practices in Exploratory Factor Analysis: Four Recommendations for Getting the Most from Your Analysis. Practical Assessment Research \& Evaluation, 10, 1-9.

Cross, R., \& Prusak, L. (2002). The People Who Make Organizations Go—Or Stop. Harvard Business Review, 80, $104-112$.

Crowley, S., \& Fan, X. (1997). Structural Equation Modeling: Basic Concepts and Applications in Personality Assessment Research. Journal of Personality Assessment, 68, 508-531. http://dx.doi.org/10.1207/s15327752jpa6803_4

Eagly, A. H., Johannesen-Schmidt, M. C., \& Van Engen, M. L. (2003). Transformational, Transactional, and Laissez-Faire Leadership Styles: A Meta-Analysis Comparing Women and Men. Psychological Bulletin, 129, 569-591. http://dx.doi.org/10.1037/0033-2909.129.4.569

Ellinger, A. D., Ellinger, A. E., \& Keller, S. B. (2003). Supervisory Coaching Behavior, Employee Satisfaction, and Warehouse Employee Performance: A Dyadic Perspective in the Distribution Industry. Human Resource Development Quarterly, 14, 435-458. http://dx.doi.org/10.1002/hrdq.1078

Ensley, M. D., Hmieleski, K. M., \& Pearce, C. L. (2006). The Importance of Vertical and Shared Leadership within New Venture Top Management Teams: Implications for the Performance of Startups. The Leadership Quarterly, 17, $217-231$. http://dx.doi.org/10.1016/j.leaqua.2006.02.002

Fleishman, E. A. (1953). The Description of Supervisory Behavior. Journal of Applied Psychology, 37, 181-210. http://dx.doi.org/10.1037/h0056314

Fornell, C., \& Larcker, D. F. (1981). Structural Equation Models with Unobservable Variables and Measurement Error: Algebra and Statistics. Journal of Marketing Research, 18, 382-388. http://dx.doi.org/10.2307/3150980

Gil, F., Rico, R., Alcover, C. M., \& Barrasa, Á. (2005). Change-Oriented Leadership, Satisfaction and Performance in Work Groups: Effects of Team Climate and Group Potency. Journal of Managerial Psychology, 20, 312-328. http://dx.doi.org/10.1108/02683940510589073

Gilley, A., Dixon, P., \& Gilley, J. W. (2008). Characteristics of Leadership Effectiveness: Implementing Change and Driving Innovation in Organizations. Human Resource Development Quarterly, 19, 153-169. http://dx.doi.org/10.1002/hrdq.1232

Glanville, J. L., \& Wildhagen, T. (2007). The Measurement of School Engagement Assessing Dimensionality and Measurement Invariance across Race and Ethnicity. Educational and Psychological Measurement, 67, 1019-1041. http://dx.doi.org/10.1177/0013164406299126

Gockel, C., \& Werth, L. (2010). Measuring and Modeling Shared Leadership. Journal of Personnel Psychology, 9, $172-180$. http://dx.doi.org/10.1027/1866-5888/a000023

Goldstein, H. (2011). Multilevel Statistical Models. Chichester: John Wiley \& Sons.

Graham, J. M., Guthrie, A. C., \& Thompson, B. (2003). Consequences of Not Interpreting Structure Coefficients in Published CFA Research: A Reminder. Structural Equation Modeling: A Multidisciplinary Journal, 10, 142-153. http://dx.doi.org/10.1207/S15328007SEM1001_7

Grohmann, A., \& Kauffeld, S. (2013). Evaluating Training Programs: Development and Correlates of the Questionnaire for Professional Training Evaluation. International Journal of Training and Development, 17, 135-155. http://dx.doi.org/10.1111/ijtd.12005

Grossman, R., \& Salas, E. (2011). The Transfer of Training: What Really Matters. International Journal of Training and Development, 15, 103-120. http://dx.doi.org/10.1111/j.1468-2419.2011.00373.x

Hackman, J. R., \& Oldham, G. R. (1975). Development of the Job Diagnostic Survey. Journal of Applied Psychology, 60, 159-170. http://dx.doi.org/10.1037/h0076546

Hair Jr., J. F., Black, W. C., Babin, B. J., \& Anderson, R. E. (2009). Multivariate Data Analysis—A Global Perspective. Boston, MA: Pearson. 
Hamstra, M. R., Van Yperen, N. W., Wisse, B., \& Sassenberg, K. (In Press). On the Perceived Effectiveness of Transformational-Transactional Leadership: The Role of Encouraged Strategies and Followers' Regulatory Focus. European Journal of Social Psychology.

Hatala, J. P. (2006). Social Network Analysis in Human Resource Development: A New Methodology. Human Resource Development Review, 5, 45-71. http://dx.doi.org/10.1177/1534484305284318

Hiller, N. J., Day, D. V., \& Vance, R. J. (2006). Collective Enactment of Leadership Roles and Team Effectiveness: A Field Study. The Leadership Quarterly, 17, 387-397. http://dx.doi.org/10.1016/j.leaqua.2006.04.004

Hmieleski, K. M., Cole, M. S., \& Baron, R. A. (2012). Shared Authentic Leadership and New Venture Performance. Journal of Management, 38, 1476-1499. http://dx.doi.org/10.1177/0149206311415419

Hoch, J. E. (2013). Shared Leadership and Innovation: The Role of Vertical Leadership and Employee Integrity. Journal of Business and Psychology, 28, 159-174. http://dx.doi.org/10.1007/s10869-012-9273-6

Hoch, J. E., \& Duhlebohn, J. H. (2013). Shared Leadership in Enterprise Resource Planning and Human Resource Management System Implementation. Human Resource Management Review, 23, 114-125. http://dx.doi.org/10.1016/j.hrmr.2012.06.007

Hoch, J. E., Dulebohn, J. H., \& Pearce, C. L. (2010a). Shared Leadership Questionnaire (SLQ): Developing a Short Scale to Measure Shared and Vertical Leadership in Teams. Visual Presentation at the Society for Industrial and Organizational Psychology (SIOP) Conference 2010, Atlanta.

Hoch, J. E., Pearce, C. L., \& Welzel, L. (2010b). Is the Most Effective Team Leadership Shared? Journal of Personnel Psychology, 9, 105-116. http://dx.doi.org/10.1027/1866-5888/a000020

Hoon Song, J., Kolb, J. A., Hee Lee, U., \& Kyoung Kim, H. (2012). Role of Transformational Leadership in Effective Organizational Knowledge Creation Practices: Mediating Effects of Employees' Work Engagement. Human Resource Development Quarterly, 23, 65-101. http://dx.doi.org/10.1002/hrdq.21120

House, R. J. (1996). Path-Goal Theory of Leadership: Lessons, Legacy, and a Reformulated Theory. The Leadership Quarterly, 7, 323-352. http://dx.doi.org/10.1016/S1048-9843(96)90024-7

Hui, R. T. Y., Sue-Chan, C., \& Wood, R. E. (2013). The Contrasting Effects of Coaching Style on Task Performance: The Mediating Roles of Subjective Task Complexity and Self-Set Goal. Human Resource Development Quarterly, 24, 429-458. http://dx.doi.org/10.1002/hrdq.21170

Johnson, R. E., Rosen, C. C., \& Djurdjevic, E. (2011). Assessing the Impact of Common Method Variance on Higher Order Multidimensional Constructs. Journal of Applied Psychology, 96, 744-761. http://dx.doi.org/10.1037/a0021504

Joshi, A. (2006). The Influence of Organizational Demography on the External Networking Behavior of Teams. Academy of Management Review, 31, 583-595. http://dx.doi.org/10.5465/AMR.2006.21318919

Judge, T. A., \& Piccolo, R. F. (2004). Transformational and Transactional Leadership: A Meta-Analytic Test of Their Relative Validity. Journal of Applied Psychology, 89, 755-768. http://dx.doi.org/10.1037/0021-9010.89.5.755

Judge, T. A., Piccolo, R. F., \& Ilies, R. (2004). The Forgotten Ones? The Validity of Consideration and Initiating Structure in Leadership Research. The Journal of Applied Psychology, 89, 36-51. http://dx.doi.org/10.1037/0021-9010.89.1.36

Kauffeld, S., \& Frieling, E. (2001). Der Fragebogen zur Arbeit im Team (F-A-T). Zeitschrift für Arbeitsund Organisationspsychologie, 45, 26-33. http://dx.doi.org/10.1026//0932-4089.45.1.26

Kauffeld, S., Jonas, E., Grote, S., Frey, D., \& Frieling, E. (2004). Innovationsklima-Konstruktion und erste Psychometrische Überprüfung eines Messinstrumentes. Diagnostica, 50, 153-164. http://dx.doi.org/10.1026/0012-1924.50.3.153

Kirkman, B. L., \& Rosen, B. (1999). Beyond Self-Management: Antecedents and Consequences of Team Empowerment. Academy of Management Journal, 42, 58-74. http://dx.doi.org/10.2307/256874

Kotter, J. P. (2001). What Leaders Really Do. Harvard Business Review, 79, 85-98.

Kowske, B. J., \& Anthony, K. (2007). Towards Defining Leadership Competence around the World: What Mid-Level Managers Need to Know in Twelve Countries. Human Resource Development International, 10, 21-41. http://dx.doi.org/10.1080/13678860601170260

Kuchinke, K. P. (1998). The Influence of Leadership Styles on Subordinates' Attitudes towards Their Leaders and towards Performance. A Comparison of US and German Manufacturing Employees. Human Resource Development International, 1, 291-308. http://dx.doi.org/10.1080/13678869800000039

Künzle, B., Zala-Mezö, E., Kolbe, M., Wacker, J., \& Grote, G. (2010). Substitutes for Leadership in Anaesthesia Teams and Their Impact on Leadership Effectiveness. European Journal of Work and Organizational Psychology, 19, 505-531. http://dx.doi.org/10.1080/13594320902986170

Lehmann-Willenbrock, N., Grohmann, A., \& Kauffeld, S. (2011). Task and Relationship Conflict at Work: Construct Validation of a German Version of Jehn's Intragroup Conflict Scale. European Journal of Psychological Assessment, 27, 171178. http://dx.doi.org/10.1027/1015-5759/a000064 
Liu, S., Hu, H., Li, Y., Wang, Z., \& Lin, Y. (2014). Examining the Cross-Level Relationship between Shared Leadership and Learning in Teams: Evidence from China. The Leadership Quarterly, 25, 282-295.

http://dx.doi.org/10.1016/j.leaqua.2013.08.006

Lowe, K. B., Kroeck, K. G., \& Sivasubramaniam, N. (1996). Effectiveness Correlates of Transformational and Transactional Leadership: A Meta-Analytic Review of the MLQ Literature. The Leadership Quarterly, 7, 385-415. http://dx.doi.org/10.1016/S1048-9843(96)90027-2

Marsh, H. W., Hau, K. \& Wen, Z. (2004). In Search of Golden Rules: Comment on Hypothesis-Testing Approaches to Setting Cutoff Values for Fit Indexes and Dangers in Overgeneralizing Hu and Bentler's Findings. Structural Equation Modeling, 11, 320-341. http://dx.doi.org/10.1207/s15328007sem1103_2

Martínez Caro, L., \& Martinez Garcia, J. A. (2007). Cognitive-Affective Model of Consumer Satisfaction: An Exploratory Study within the Framework of a Sporting Event. Journal of Business Research, 60, 108-114. http://dx.doi.org/10.1016/j.jbusres.2006.10.008

Mathisen, G. E., Torsheim, T., \& Einarsen, S. (2006). The Team-Level Model of Climate for Innovation: A Two-Level Confirmatory Factor Analysis. Journal of Occupational and Organizational Psychology, 79, 23-35. http://dx.doi.org/10.1348/096317905X52869

McIntyre, H. H., \& Foti, R. J. (2013). The Impact of Shared Leadership on Teamwork Mental Models and Performance in Self-Directed Teams. Group Processes \& Intergroup Relations, 16, 46-57. http://dx.doi.org/10.1177/1368430211422923

Mehra, A., Smith, B. R., Dixon, A. L., \& Robertson, B. (2006). Distributed Leadership in Teams: The Network of Leadership Perceptions and Team Performance. The Leadership Quarterly, 17, 232-245. http://dx.doi.org/10.1016/j.leaqua.2006.02.003

Morgeson, F. P., DeRue, D. S., \& Karam, E. P. (2010). Leadership in Teams: A Functional Approach to Understanding Leadership Structures and Processes. Journal of Management, 36, 5-39. http://dx.doi.org/10.1177/0149206309347376

Muthén, L. K., \& Muthén, B. (2012). 1998-2012. Mplus User’s Guide (7th ed.). Los Angeles, CA: Muthén \& Muthén.

Nakamura, Y. T., \& Yorks, L. (2011). The Role of Reflective Practices in Building Social Capital in Organizations from an HRD Perspective. Human Resource Development Review, 10, 222-245. http://dx.doi.org/10.1177/1534484311411076

Newman, J. (2005). Enter the Transformational Leader: Network Governance and the Micro-Politics of Modernization. Sociology, 39, 717-734. http://dx.doi.org/10.1177/0038038505056029

Nijstad, B. A., Berger-Selman, F., \& De Dreu, C. K. W. (2014). Innovation in Top Management Teams: Minority Dissent, Transformational Leadership, and Radical Innovations. European Journal of Work and Organizational Psychology, 23, 310-322. http://dx.doi.org/10.1080/1359432X.2012.734038

Noe, R. A. (2002). Employee Training and Development. Boston, MA: McGraw-Hill.

Pearce, C. L., \& Manz, C. C. (2005). The New Silver Bullets of Leadership: The Importance of Self- and Shared Leadership Knowledge Work. Organizational Dynamics, 34, 130-140. http://dx.doi.org/10.1016/j.orgdyn.2005.03.003

Pearce, C. L., \& Sims Jr., H. P. (2002). Vertical versus Shared Leadership as Predictors of the Effectiveness of Change Management Teams: An Examination of Aversive, Directive, Transactional, Transformational, and Empowering Leader Behaviors. Group Dynamics: Theory, Research, and Practice, 6, 172-197. http://dx.doi.org/10.1037/1089-2699.6.2.172

Pearce, C. L., Hoch, J. E., Jeppesen, H. J., \& Wegge, J. (2010). New Forms of Management. Journal of Personnel Psychology, 9, 151-153. http://dx.doi.org/10.1027/1866-5888/a000022

Podsakoff, P. M., MacKenzie, S. B., Lee, J. Y., \& Podsakoff, N. P. (2003). Common Method Biases in Behavioral Research: A Critical Review of the Literature and Recommended Remedies. Journal of Applied Psychology, 88, 879-903. http://dx.doi.org/10.1037/0021-9010.88.5.879

Raftery, A. E. (1995). Bayesian Model Selection in Social Research. Sociological Methodology, 25, 111-164. http://dx.doi.org/10.2307/271063

Saks, A. M., Tamkin, P., \& Lewis, P. (2011). Management Training and Development. International Journal of Training and Development, 15, 179-183. http://dx.doi.org/10.1111/j.1468-2419.2011.00381.x

Schmidt, K. H., \& Kleinbeck, U. (1999). Job Diagnosticsurvey (JDS-Deutsche Fassung). In H. Dunckel, (Eds.), Handbuch Psychologischer Arbeitsanalyseverfahren (pp. 205-230). Zürich: vdf Hochschulverlag.

Seltzer, J., \& Bass, B. M. (1990). Transformational Leadership: Beyond Initiation and Consideration. Journal of Management, 16, 693-703. http://dx.doi.org/10.1177/014920639001600403

Sheehan, M., Garavan, T. N., \& Carbery, R. (2014). Innovation and Human Resource Development (HRD). European Journal of Training and Development, 38, 2-14. http://dx.doi.org/10.1108/EJTD-11-2013-0128

Shrout, P. E., \& Yager, T. J. (1989). Reliability and Validity of Screening Scales: Effect of Reducing Scale Length. Journal of Clinical Epidemiology, 42, 69-78. http://dx.doi.org/10.1016/0895-4356(89)90027-9 
Shuck, B., \& Herd, A. M. (2012). Employee Engagement and Leadership Exploring the Convergence of Two Frameworks and Implications for Leadership Development in HRD. Human Resource Development Review, 11, 156-181. http://dx.doi.org/10.1177/1534484312438211

Singh, R. N., \& Mohanty, R. P. (2011). Participation Satisfaction and Organizational Commitment: Moderating Role of Employee’s Cultural Values. Human Resource Development International, 14, 583-603. http://dx.doi.org/10.1080/13678868.2011.621286

Small, E. E., \& Rentsch, J. R. (2010). Shared Leadership in Teams. Journal of Personnel Psychology, 9, $203-211$. http://dx.doi.org/10.1027/1866-5888/a000017

Stöber, J. (2001). The Social Desirability Scale-17 (SDS-17): Convergent Validity, Discriminant Validity, and Relationship with Age. European Journal of Psychological Assessment, 17, 222-232. http://dx.doi.org/10.1027//1015-5759.17.3.222

Thompson, B. (2005). Exploratory and Confirmatory Factor Analysis: Understanding Concepts and Applications. Washington DC: American Psychological Association.

Waite, A. M. (2013). Leadership’s Influence on Innovation and Sustainability: A Review of the Literature and Implications for HRD. European Journal of Training and Development, 38, 15-39. http://dx.doi.org/10.1108/EJTD-09-2013-0094

Waldman, D. A., Bass, B. M., \& Einstein, W. O. (1987). Leadership and Outcomes of Performance Appraisal Processes. Journal of Occupational Psychology, 60, 177-186. http://dx.doi.org/10.1111/j.2044-8325.1987.tb00251.x

Walumbwa, F. O., Orwa, B., Wang, P., \& Lawler, J. J. (2005). Transformational Leadership, Organizational Commitment, and Job Satisfaction: A Comparative Study of Kenyan and US Financial Firms. Human Resource Development Quarterly, 16, 235-256. http://dx.doi.org/10.1002/hrdq.1135

Wang, D., Waldman, D. A., \& Zhang, Z. (2014). A Meta-Analysis of Shared Leadership and Team Effectiveness. Journal of Applied Psychology, 99, 181-198. http://dx.doi.org/10.1037/a0034531

Wang, J., \& Wang, X. (2012). Structural Equation Modeling: Applications using Mplus. Chichester: John Wiley \& Sons. http://dx.doi.org/10.1002/9781118356258

Wasylyshyn, K. M. (2003). Executive Coaching: An Outcome Study. Consulting Psychology Journal: Practice and Research, 55, 94-106. http://dx.doi.org/10.1037/1061-4087.55.2.94

Wegge, J., Jeppesen, H. J., Weber, W. G., Pearce, C. L., Silva, S. A., Piecha, A. et al. (2010). Promoting Work Motivation in Organizations. Journal of Personnel Psychology, 9, 154-171. http://dx.doi.org/10.1027/1866-5888/a000025

West, M. (1999). Micropolitics, Leadership and All That: The Need to Increase the Micropolitical Awareness and Skills of School Leaders. School Leadership \& Management, 19, 189-195. http://dx.doi.org/10.1080/13632439969195

West, M. A. (2012). Effective Teamwork: Practical Lessons from Organizational Research. Chichester: John Wiley \& Sons.

Williams, F., \& Foti, R. J. (2011). Formally Developing Creative Leadership as a Driver of Organizational Innovation. Advances in Developing Human Resources, 13, 279-296. http://dx.doi.org/10.1177/1523422311424702

Wolff, H.-G., \& Moser, K. (2009). Effects of Networking on Career Success: A Longitudinal Study. The Journal of Applied Psychology, 94, 196-206. http://dx.doi.org/10.1037/a0013350

Yukl, G. (1999). An Evaluative Essay on Current Conceptions of Effective Leadership. European Journal of Work and Organizational Psychology, 8, 33-38. http://dx.doi.org/10.1080/135943299398429

Yukl, G., \& van Fleet, D. D. (1992). Theory and Research on Leadership in Organisations. In M. D. Dunnette, \& L. M. Hough (Eds.), Handbook of Industrial and Organizational Psychology, Vol. 3 (pp. 147-197). Palo Alto, CA: Consulting Psychologists Press.

Yukl, G., Gordon, A., \& Taber, T. (2002). A Hierarchical Taxonomy of Leadership Behavior: Integrating a Half Century of Behavior Research. Journal of Leadership \& Organizational Studies, 9, 15-32. http://dx.doi.org/10.1177/107179190200900102

Zhang, M., Zheng, W., \& Wei, J. (2009). Sources of Social Capital: Effects of Altruistic Citizenship Behavior and Job Involvement on Advice Network Centrality. Human Resource Development Quarterly, 20, 195-217.

http://dx.doi.org/10.1002/hrdq.20015 
Scientific Research Publishing (SCIRP) is one of the largest Open Access journal publishers. It is currently publishing more than 200 open access, online, peer-reviewed journals covering a wide range of academic disciplines. SCIRP serves the worldwide academic communities and contributes to the progress and application of science with its publication.

Other selected journals from SCIRP are listed as below. Submit your manuscript to us via either submit@scirp.org or Online Submission Portal.
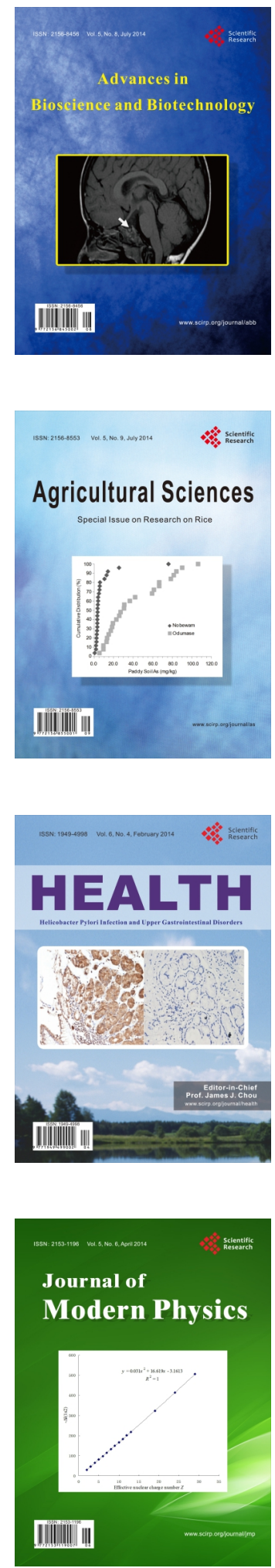
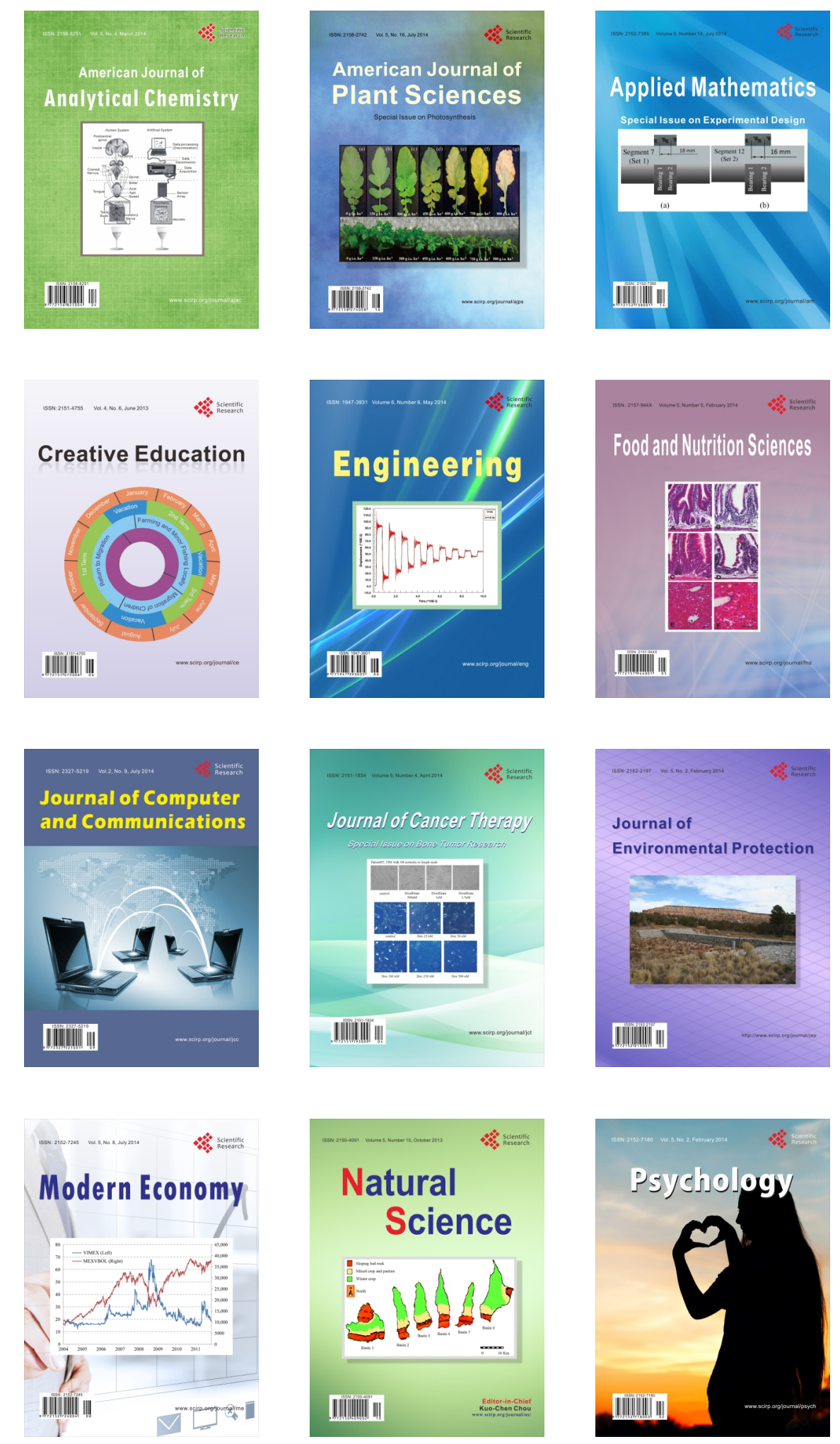